\title{
有限要素法による不連続性体の応力・変形・浸透流解析 COUPLED STRESS FLOW ANALYSIS OF DISCONTINUOUS MEDIA BY FINITE ELEMENTS
}

\author{
大 西 有 三*.大 津 宏 康** \\ By Yuzo OHNISHI and Hiroyasu OHTSU
}

\section{1.はじめに}

現実の地盤あるいは岩盤は均質というより不均質な場 合が多く，かつまた割れ目，断層，破砕帯などの不連続 な部分を含んでいる.これら不連続な部分は力学的にも 水理学的にも地盤あるいは岩盤の挙動に多大の影響を及 ぼす．このような不連続性体の解析を行うことは容易で はないが，最近では有限要素法を主体とした数值解析に よる応力・変形解析が実施されている ${ }^{11}$. なかでも特定 の不連続面を考慮し，岩盤などの非弾性特性を加味して 解析するための手段としてジョイント要素が数多く利用 されている2).

一方，不連続性体の水理特性についても少なからず関 心が払われてきた．不連続性岩盤においては，その透水 性は岩石そのものより数オーダー大きいといわれてい $る^{3)}$.また，岩盤内の水の貯留はおもに不連続な部分に よると考えられるため, 不連続性地盤や岩盤内での不連 続面の挙動を知ることはきわめて有意義であることはい うまでもない，ところが実際には連続性解析による挙動 把握が主流を占めている，その理由は，割れ目の透水性 を求めるのが困難なこと, 複雑な割れ目システムをどの ようにモデル化するか確定していないことなどによると 思われる. しかし，解析の対象となる構造物に比較して 岩盤の平均的な割れ目の間隔 (spacing) が大きい場合に は連続性解析は不適当だとして，Wilson ら ${ }^{4}$ はその目安 を提示している.このような観点から不連続性岩盤の水 理学的解析を行らにあたって，不連続面内の水の流れを モデル化することから研究が始められたが，その最初の ものが平行板モデルである．これは独立した不連続面 (ジョイント) 内の流れとして, 滑らかな 2 枚の平板の 間を流れる非圧縮性粘性流体を仮定したもので，このモ

* 正会員 Ph.D. 京都大学助教授 工学部交通土木工学科

** 正会員 工修 大成建設土木本部設計部
デルはさらに有限要素法による不連続性岩盤の数值解析 に利用された 不連続面（ジョイント）から成ると仮定し, ジョイント 内の水の流れは層流である。

不連続面内の水の流れについては理論解析以外に数多 くの室内実験の結果が報告されている．また，現実の問 題と対応させるため三次元モデルによる実験 ${ }^{6}$ や原位置 での試験の結果 ${ }^{7}$ が研究成果として発表されつつある。 他方, 不連続性岩盤内の透水特性を巨視的に表現する特 別なモデルとして，2 重間幥モデル (double porosity model $)^{8)}$ と異方性モデル (anisotropic model) ${ }^{9)}$ が考え られている.いずれも石油工学と関連した揚水問題の解 析に用いられてきたものであり，統計的概念を加味して 非常に数学的技巧を要するのでそれほど実用的とはいい がたい

このような研究が進められる中で，ジョイントが剛で ある（水圧によるジョイントの開閉がない）とする仮定 に疑問が呈示されてきた. Snow ${ }^{10)}$ はジョイント内の流 れはジョイントの変位に大きく影響されると強調し， Bernaix $^{11)}$ が実験的にその事実を証明，マルパッセダム の破壊原因との関連性を説明した。こうした研究をもと に, 不連続面内の水の流れと岩盤の応力・変形との相互 作用に注目して有限要素法を用いた解析を示したのが Noorishad ら ${ }^{12)}$ である. 彼らは，応力・変形解析ではジ ョイント要素を, 浸透流の解析では 1 次元線要素を利用 し，2 つの系からなる解析領域を交互に解くことにより 答を得ている.この手法は最近山上 ${ }^{13)}$ によって圧密解析 に適用されているものと同じ範ちゅうに属するものであ るが，解析上の手法として 2 ステップに分けて繰り返し 計算を行うため, 理論構成上，また計算技巧上煩雑にな ることは避けられない。

著者らは Biot の基本方程式に基づいて, 連続多孔質 体の応力・変形解析と浸透流解析を組み合わせたカップ リング問題解析手法を提示した ${ }^{14)}$. 本論文では同様な手 
法を不連続性地盤ならびに岩盤に適用できるよらに改良 し，その適用例を示して手法の妥当性を検討した.

\section{2. 不連続面 (ジョイント) を対象とするカッ プリング問題における支配式について}

応力・変形解析と浸透流解析の組合せであるカップリ ング問題ではつり合い式と連続式を連立させたものが支 配式となる ${ }^{14)}$. 不連続面を対象としたカップリング問題 においても支配式は連続な多孔質地盤のものと同じ形を とるが, 次のように内容が多少異なる.

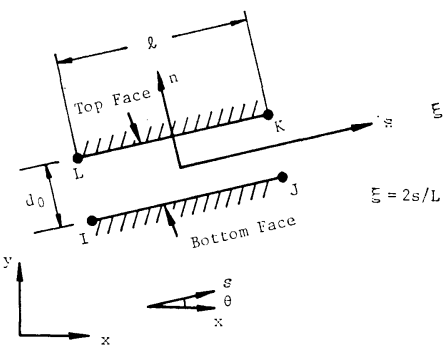

図一1 ジョイント要素

\section{（1） ジョイントにおけるつり合い式}

応力・変形解析において不連続面を表わすものとし て, Goodman ら ${ }^{2)}$ のジョイント要素を用いる. 図一1の ように 2 枚の平行板からなるジョイント要素では全体座 標系として $x-y$ 座標を, 局所座標系として $s-n$ 座標を 採用するのが通例である. ジョイント要素の壁に加わる 垂直応力を $\Delta \sigma_{n}$, せん断応力を $\Delta \tau_{n s}$ とすると, 節点の 外力増分との関係は次式で表わされる ${ }^{15}$.

$$
\left\{\begin{array}{l}
\Delta F_{s, I} \\
\Delta F_{n, I} \\
\Delta F_{s, J} \\
\Delta F_{n, J} \\
\Delta F_{s, K} \\
\Delta F_{n, K} \\
\Delta F_{s, L} \\
\Delta F_{n, L}
\end{array}\right\}=\left[\begin{array}{cc}
-\frac{l}{2} & 0 \\
0 & -\frac{l}{2} \\
-\frac{l}{2} & 0 \\
0 & -\frac{l}{2} \\
\frac{l}{2} & 0 \\
0 & \frac{l}{2} \\
\frac{l}{2} & 0 \\
0 & \frac{l}{2}
\end{array}\right\}\left\{\begin{array}{c}
\Delta \tau_{n s} \\
\Delta \sigma_{n}
\end{array}\right\}
$$

すなわち

$$
\{\Delta F\}_{s, n}=\left[B_{J}\right]\left\{\Delta \sigma_{J}\right\}_{s, n}
$$

このジョイントのつり合い式に有効応力の原理を導入す ると次のようになる。

$$
\left\{\begin{array}{c}
\Delta \tau_{n s} \\
\Delta \sigma_{n}
\end{array}\right\}=\left\{\begin{array}{l}
\Delta \tau_{n s} \\
\Delta \sigma_{n}{ }^{\prime}
\end{array}\right\}+\chi^{J} u\left\{\begin{array}{l}
0 \\
1
\end{array}\right\}
$$

ここに, $\Delta \sigma_{n}{ }^{\prime}$ はジョイント内の有効垂直応力であり,$u$ は間嚐水圧を示す．また $\chi^{J}$ は, 不飽和土の有効応力を 定義するときに ${ }^{14)}$ Bishop が提案したパラメーター $\chi$ を 不飽和状態の不連続面の解析に用いたものである.

ジョイント要素では通常のひずみに対する量として相 対変位 $\left(s\right.$ 方向 $u_{0}, n$ 方向 $v_{0}$ ) を用いるが，各節点変 位との関係は次式で示される。

$$
\begin{aligned}
\left\{\varepsilon^{J}\right\} & =\left\{\begin{array}{l}
u_{0} \\
v_{0}
\end{array}\right\} \\
& =\left\{\begin{array}{cccccccc}
-\frac{1}{2} & 0 & -\frac{1}{2} & 0 & \frac{1}{2} & 0 & \frac{1}{2} & 0 \\
0 & -\frac{1}{2} & 0 & -\frac{1}{2} & 0 & \frac{1}{2} & 0 & \frac{1}{2}
\end{array}\right\}\left\{\begin{array}{c}
u_{I} \\
v_{I} \\
u_{J} \\
v_{J} \\
u_{K} \\
v_{K} \\
u_{L} \\
v_{L}
\end{array}\right\}
\end{aligned}
$$

また，ダイレイタンシーのないジョイント (nondilatant joint）の構成関係は次のような形になる.

$$
\left\{\begin{array}{l}
\Delta \tau_{n s} \\
\Delta \sigma_{n}{ }^{\prime}
\end{array}\right\}=\left[\begin{array}{cc}
K_{s} & 0 \\
0 & K_{n}
\end{array}\right]\left\{\begin{array}{l}
u_{0} \\
v_{0}
\end{array}\right\}
$$

ここに， $K_{s}$ はせん断剛性率， $K_{n}$ は垂直剛性率である. 全水頭 $h$ と位置水頭 $z$ との関係は

$$
h=z+u / r_{w}
$$

で示される. ここで $\gamma_{w}$ は水の単位体積重量である.

以上の式を組み合わせるとジョイントにおけるつり合 い式が得られるが，連続多孔質体に打ける式と調和させ るため厳密には正しくないが便宜的なテンソル表示を以 下のように使用する。

$$
\left[\frac{1}{2} C^{J_{i j k l}}\left(u_{k, l}+u_{l, k}\right)+\chi^{J} \delta_{i j} r_{w} h\right]_{, j}+\bar{\rho} f_{i}=0
$$

ここに, $\bar{\rho}=\rho-\chi^{J} \delta_{i j} \tau_{w} \delta_{i 3}$ であり,$C^{J}{ }_{i j k l}$ はジョイン トの剛性率を示す.

\section{（2） ジョイントにおける水の挙動}

ジョイントにおける水の流れは，その不連続面の方向 に卓越するということに着目し，図一2 に示すような準 1 次元的な流れとする. 準 1 次元的といらのは，水の流 れを 1 次元とするが，その他に周辺多孔質体から不連続

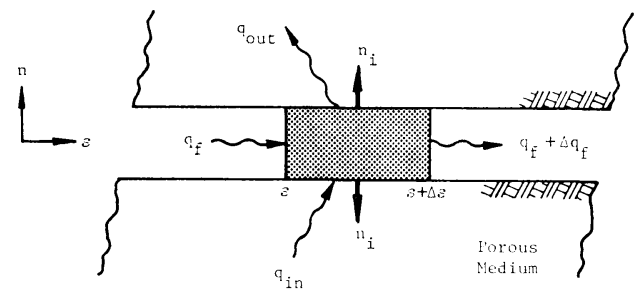

図一2 ジョイント内の水の流れ 
面への水の流出・流入を考慮しているからである.

質量保存則より不連続面内での水の連続式は連続多孔 質体の場合とまったく同じように次式で示される.

$$
-\operatorname{div}\left(\rho_{f} v_{f}\right)-q=\frac{\partial}{\partial t}\left(\rho_{f} \theta\right)
$$

ここに, $\rho_{f}$ は間隙流体の密度, $v_{f}$ は流速, $q$ は系への 流出流入量, $\theta$ は体積含水率を表わす.

式 (8) の右辺は連続式における変形との連成項を含ん でいて次の式に変換できる.

$$
\frac{\partial}{\partial t}\left(\rho_{f} \theta\right)=\rho_{f}\left(S_{r}^{J} \frac{\partial u_{i, i}}{\partial t}+C^{J}(\psi) \frac{\partial \psi}{\partial t}\right)
$$

式 (9) における $C^{J}(\psi)$ は Biot の圧密理論における係 数 $1 / M$ に相当するものである. ジョイント間隚が水で 満たされている場合には $S_{r}{ }^{J}=1$ で, かつ $C^{J}(\psi) \simeq 0$ となり, 式 (9) の右辺は変形に伴うジョイントの体積ひ ずみのみを表わすことになる。

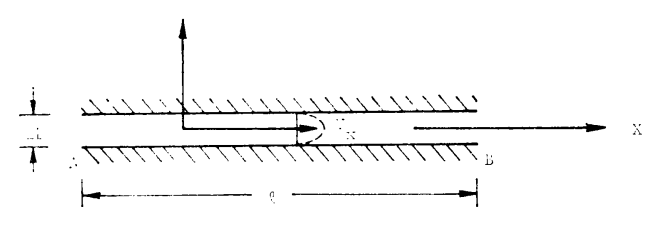

図一3 平行板モデル

次に, 土中水の運動方程式について考察する. 通常多 孔質体内の水の流れは, 層流であると Darcy の法則が 適用される. しかし, ジョイントの中を流れる水は連続 体内のものと多少流れの形態が異なるため, 特別な形の 運動方程式が必要となる. したがって解析では, ジョイ ントを滑らかな平板と仮定し，その間を流れる非圧縮性 流体の理論 (図一3) から, 平均流速を $v_{0}$ として次式を 導いている ${ }^{12)}$. 2 点間の動水勾配を $I$ とすると,

$$
v_{0}=\frac{r_{w}(2 b)^{2}}{12 \mu} I
$$

ここに, $b$ は板の間隔の半分であり, $\mu$ は粘性係数であ る. したがって, 2 枚の平板の間を流れる流体を Darcy の法則に従うものと仮定し, 相当する透水係数 $K^{J}$ を求 めると

$$
v_{0}=K^{J} \cdot I ; K^{J}=\frac{r_{w}(2 b)^{2}}{12 \mu}
$$

が得られる。

式（8）に式 (9)，(11）を代入すると

$$
\operatorname{div}\left(K^{J} \nabla h\right)+\bar{q}=S_{r} \frac{\partial u_{i, i}}{\partial t}+C^{J}(\psi) \frac{\partial \psi}{\partial t} \cdots
$$

$$
\text { ここに, } \bar{q}=-q / \rho_{f}
$$

上記の式を導くにあたって問題となるのは，ジョイン トが不飽和状態になったときにどのような取扱いをする かである. 連続多孔質体の場合は近似的に $\chi=S_{r}$ とい
ら仮定を設けて処理すると妥当な結果が得られるが実測 結果に乏しい. 現時点ではジョイントについてはなおさ らその測定が困難であると思われる。そこで, 本研究に おいては不飽和領域のジョイントの取扱いとして, 式 (7) に示すつり合い式において $\chi^{J}=0$ として間幥水圧の 項を無視し,さらに式 (12) に示す不連続部での連続式 は考慮しないものとする. すなわち, 不連続部が不飽和 領域になった場合には, 間嚐流体の効果を無視した全応 力計算のみを行うものとする. その結果として， 飽和一 不飽和領域を考慮したジョイント内での 2 相系問題の基 本式は次の連立方程式で与えられる.

$$
\left.\begin{array}{l}
{\left[\frac{1}{2} C^{J}{ }_{i j k l}\left(u_{k, l}+u_{l, k}\right)+\chi^{J} \delta_{i j} r_{w} h\right]_{, j}} \\
\quad+\left(\rho-\delta_{i j} \gamma_{w} \chi^{J} \delta_{i 3}\right) f_{i}=0 \\
\operatorname{div}\left(K^{J} \nabla h\right)+\bar{q}-S_{r} J \frac{\partial u_{i, i}}{\partial t}-C^{J}(\psi) \frac{\partial \psi}{\partial t}=0
\end{array}\right\}
$$

式（13）を解くためには初期条件と境界条件（変位, 応 力, 全水頭, 流量の各既知境界) が必要なことはいらま でもない.

\section{3. 有限要素法による定式化}

重みつき残差法の一つである Galerkin 法を用いてジ ヨイントに対する式（13）を定式化する．変位および全 水頭を未知数とし; それぞれの内㨋関数を用いて分割要 素の節点変位, 節点全水頭と関連づける.ここで, 変位 に対しては図一1に示すジョイント要素を用いる.すな わち

$$
\left.\begin{array}{l}
u_{i}^{B}=N_{1} u_{i}^{I}+N_{2} u_{i}^{J} \\
u_{i}^{T}=N_{1} u_{i}^{L}+N_{2} u_{i}^{K}
\end{array}\right\}
$$

ここに，Bは下部 (Bottom) を， $T$ は上部 (Top) を表 わす. また, $N_{1}=(1-\xi) / 2, N_{2}=(1+\xi) / 2, \xi=2 \Delta / L$ で ある・

一方，全水頭に対しては 図-4 に示す 1 次元アイソ パラメトリック要素を利用 する.

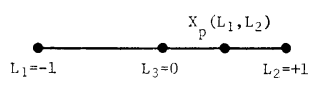

図-41 次元アインパラ メトリック要素

$$
h=\bar{N}_{i} h_{i}[i=1,2]
$$

ここに, $\bar{N}_{1}=(1-\xi) / 2, \quad \bar{N}_{2}=(1+\xi) / 2, \quad \xi=2 \Delta / L$

式（13）に式（14），(15）を用いて Galerkin 法を適用 し, Gauss-Green の定理を使って整理すると以下の式と なる.

$$
\left.\begin{array}{l}
K_{n m}^{i K_{\bar{u}}}{ }_{K}^{m}+C_{n m}{ }^{i} \bar{h}^{m}=F_{n}{ }^{i} \\
H_{n m} \bar{h}^{m}+L_{n m}{ }^{i} \frac{\partial}{\partial t} \bar{u}_{i}^{m}+E_{n m} \frac{\partial}{\partial t} \bar{h}^{m}-Q_{n}=0
\end{array}\right\}
$$




$$
\begin{aligned}
& K_{n m}{ }^{i K}=\sum_{a=1}^{N_{0}} \int_{V_{a}} N_{n, j} C^{J}{ }_{i j k l} N_{m, l} d V_{a} \\
& C_{n m}{ }^{i}=\sum_{a=1}^{N_{0}} \int_{V_{a}} N_{n, j} \chi^{J} \delta_{i j} r_{w} \bar{N}_{m} d V_{a} \\
& F_{n}{ }^{i}=\sum_{a=1}^{N_{0}} \int_{V_{a}} N_{n} \bar{\rho} f_{i} d V_{a}+\sum_{a=1}^{N_{0}} \int_{S_{a}} N_{n} N_{m} \hat{T}_{m} d S_{a} \\
& H_{n m}=\sum_{a=1}^{N_{0}} \int_{V_{a}} \bar{N}_{n, i} K^{J} N_{m, i} d V_{a} \\
& L_{n m}{ }^{i}=\sum_{a=1}^{N_{0}} \int_{V_{a}} \bar{N}_{n} S_{r}{ }^{J} N_{m, i} d V_{a} \\
& E_{n m}=\sum_{a=1}^{N_{0}} \int_{V_{a}} \bar{N}_{n} C^{J}(\psi) N_{m} d V_{a} \\
& Q_{n}=\sum_{a=1}^{N_{0}} \int_{S_{a}} \bar{N}_{n} \bar{N}_{m} \hat{Q}^{m} d S_{a}-\sum_{a=1}^{N_{0}} \int_{V_{a}} \bar{N}_{n} \bar{q} d V_{a}
\end{aligned}
$$

また, $V_{a}, S_{a}$ はそれぞれ $a$ 番目の要素の体積と面積で あり, $N_{0}$ は要素総数, $\hat{T}_{i}{ }^{m}$ は表面力, $\hat{Q}^{m}$ は節点流量 を示す. 式 (16) の時間微分に対して中央差分を採用し， つり合い式を増分表示にし, $C_{n m}{ }^{i}$ が近似的に $L_{n m}{ }^{i}$ に ほぼ等しいとすると, 基本式はマトリックス表示で,

$$
\begin{gathered}
{\left[\begin{array}{cc}
\boldsymbol{K}^{J} & \boldsymbol{C}^{J} \\
\left(\boldsymbol{C}^{J}\right)^{T} & \boldsymbol{H}^{J}(\Delta t / 2)+\boldsymbol{E}^{J}
\end{array}\right]\left\{\begin{array}{c}
\Delta u \\
h_{t+\Delta t}
\end{array}\right\}} \\
\quad=\left\{\begin{array}{c}
\Delta \boldsymbol{F}+\boldsymbol{C}^{J} h_{t} \\
\bar{Q}_{n}+\left[\boldsymbol{H}^{J}(-\Delta t / 2)+\boldsymbol{E}^{J}\right] h_{t}
\end{array}\right\}
\end{gathered}
$$

となる. $\bar{Q}_{n}=\frac{\Delta t}{2}\left(Q^{n}{ }_{t+\Delta t}+Q_{t}{ }^{n}\right)$ であり, 上指標 $J$ はシ ヨイントに対することを示す.

一方，連続多孔質体における 飽和一不飽和領域を含ん だ浸透を考慮した応力・変形解析の基本式はすでに発表 されているとおり次の形で与えられる.

$$
\begin{aligned}
& {\left[\begin{array}{cc}
\boldsymbol{K} & \boldsymbol{C} \\
\boldsymbol{C}^{T} & \boldsymbol{H}(\Delta t / 2)+\boldsymbol{E}
\end{array}\right]\left\{\begin{array}{c}
\Delta u \\
h_{t+\Delta t}
\end{array}\right\}} \\
& =\left\{\begin{array}{c}
\Delta \boldsymbol{F}+\boldsymbol{C} h_{t} \\
\bar{Q}_{n}+[\boldsymbol{H}(-\Delta t / 2)+\boldsymbol{E}] h_{t}
\end{array}\right\}
\end{aligned}
$$

したがって, 式（17）と式（18）を併用し，初期条件な らびに境界条件を加味して未知数 $\left(\Delta u, h_{t+\Delta t}\right)$ を求める ことが, 不連続面を有する地盤および岩盤の浸透を考慮 した応力・変形解析（カップリング問題）の解を得るこ ととなる.

有限要素法で式 (17)，（18）を解く場合，全体剛性マ トリックス組立て時に次の点に注意を払わねばならな い. まず定式化の段階で本解析手法は，(a）2 次元アイ ソパラメトリック要素, (b) 1 次元アイソパラメトリッ ク要素, (c) ジョイント要素という3つの要素を用いて いる.

このうち，(a)，(b) のアイソパラメトリック要素はヤ コビアンマトリックスを介在して自動的に局所座標系か ら全体座標系へと変換される. これに対し, ジョイント 要素においては局所座標系 $(s, n)$ から全体座標系 $(x$, $y)$ 一の特別な変換措置が必要となる。図一1 において
ある節点 $i$ に対する局所座標系 $(s, n)$ での変位を $\left(u_{s}{ }^{i}\right.$, $\left.u_{n}{ }^{i}\right)$, 全体座標系での変位を $\left(u_{x}{ }^{i}, u_{y}{ }^{i}\right)$ とすると両者の 関係は次のようになる。

$$
\left\{\begin{array}{l}
u_{s}^{i} \\
u_{n}{ }^{i}
\end{array}\right\}=\left[\begin{array}{cc}
\cos \theta & \sin \theta \\
-\sin \theta & \cos \theta
\end{array}\right]\left\{\begin{array}{l}
u_{x}{ }^{i} \\
u_{y}{ }^{i}
\end{array}\right\}
$$

つまり, ジョイント要素に対しては式（19）に示す形で 回転移動による座標変換を行わなければならない.

次に, 2 次元要素と 1 次元要素を併用するときの手法 について説明する. 図一5 に通常の四辺形要素の場合を (a), ジョイント要素がある場合を（b）として示した. この例では両者の総節点数および総要素数は一致してい る.（a）の場合には各節点での未知数は $x$ 方向変位, $y$ 方向変位, 全水頭の 3 個となり，方程式の数 は節点の 3 倍となる. これに対し，(b) のジ ヨイントを含むときに は水の流れを 1 次元的 なものとしているの で, ジョイント要素の 向かい合ら上下の対と なる 2 節点での全水頭 は同じと仮定する.し たがって，連続多孔質 体に対する剛性マトリ ックズ $(12 \times 12)$ で あるのに，ジョイント に対するものは（10× 10）に変化する. 図一
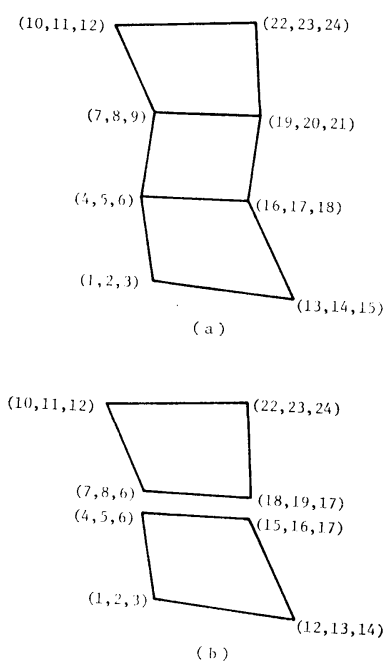

図一5 未知数の比較

5 に示す節点での未知数番号が (L 1, L 2, L 3) の方程 式番号に対応するものとすれば，ジョイントでの番号 L 3 はジョイント要素とその隣り合う上下の要素の合計 3 つの要素における流れの方程式成分を重ね合わせること になる

\section{4. ジョイントの構成関係}

ジョイント要素を含んだ解析は材料自身の非線形性を 考虑するため繰り返し計算を必要とする. 一方, 浸透解 析においても浸出面を決定するのに繰り返し計算を行う が，この場合は境界条件を適宜修正するもので材料特性 に関するものではない. したがって, カップリング問題 では 2 重の意味で繰り返し計算を行らため, その手順に 十分な配慮をしなければならない。

本節ではジョイント要素の材料非線形特性の取扱いに ついて述べるが，その骨子はすでに Goodman ${ }^{15)}$ が発表 しているものである.その内容は図一6に示すとおりで 


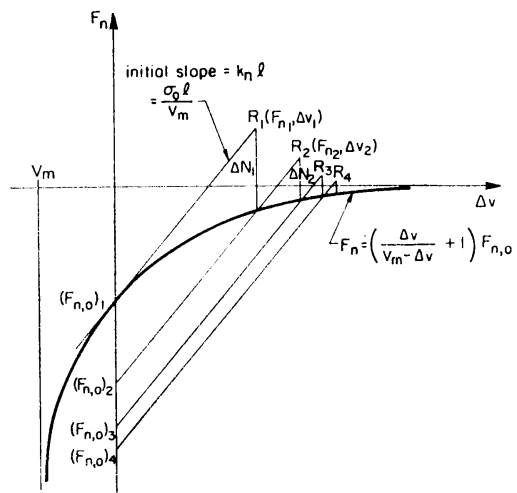

(a) 開口

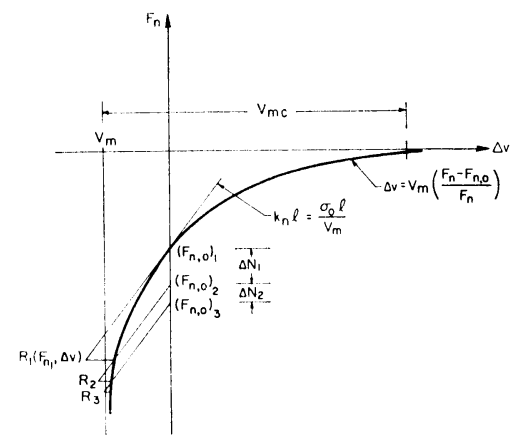

(b) 閉 合

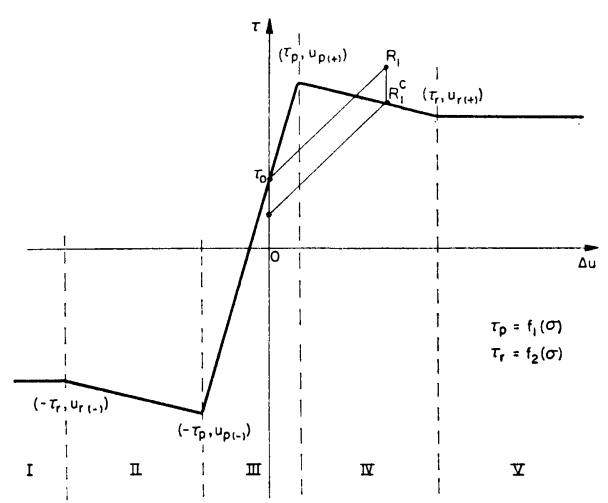

(c) 世 ん断

図一6 ジョイントの反復計算過程

あり，繰り返し計算の手法として初期応力法を用いる.

\section{（1） ジョイントの開口（opening）}

ジョイントに作用する荷重と変位の関係式を以下のよ らに定義する.

$$
F_{n}=\left(\frac{\Delta v}{V_{m}-\Delta v}+1\right) F_{n, 0}
$$

ここに, $F_{n, 0}$ は初期節点外力, $\Delta v$ は垂直力の増分 $\left(F_{n}\right.$ $\left.-F_{n, 0}\right)$ によって生じる垂直方向の変位差, $V_{m}$ は初期 の荷重 $F_{n, 0}$ から始まり閉じることのできる変位量の最
大值， $V_{m c}$ は圧縮による閉合量の最大值である.

図一6（a）に打いて，第1 ステップの解として $R_{1}$ $\left(F_{n 1}, \Delta v_{1}\right)$ が得られる. この解 $R_{1}$ は式 (20) を満足し ない場合がほとんどである．そこで $\Delta v=\Delta v_{1}$ の構成曲 線上の点を $R_{1}{ }^{C}$ と定義し, $R_{1}-R_{1}{ }^{C}$ の荷重を修正荷重 とすると，

$$
\left.\begin{array}{l}
\left(F_{n, 0}\right)_{2}=\left(F_{n, 0}\right)_{1}+\Delta N_{1} \\
\Delta N_{1}=\left(\frac{\Delta v_{1}}{V_{m}-\Delta v_{1}}+1\right) F_{n, 0}-F_{n, 1}
\end{array}\right\}
$$

ここで, ジョイント要素の長さを $l$, 単位垂直剛性率を $K_{n}$ とすると，第 $(i+1)$ 番目の反復計算過程は次式で 示される.

$$
\left.\begin{array}{l}
F_{n, i}=l K_{n} \Delta v_{i}+\left(F_{n, 0}\right)_{i} \\
\left(F_{n, 0}\right)_{i+1}=\left(F_{n, 0}\right)_{i}+\left(\Delta N_{i}\right) \\
\Delta N_{i}=\left(\frac{\Delta v_{1}}{V_{m}-\Delta v_{i}}+1\right) F_{n, 0}-F_{n, i}
\end{array}\right\}
$$

\section{（2） ジョイントの閉合（closing）}

ジョイントの閉合を考える場合の手順は開口の場合と ほとんど同じである．図一6（b) を参考にして荷重伝達 の式を導くと，

$$
\left.\begin{array}{l}
F_{n, i}=l K_{n} \Delta v_{i}+\left(F_{n, 0}\right)_{i} \\
\left(F_{n, 0}\right)_{i+1}=\left(F_{n, 0}\right)_{i}+\Delta N_{i} \\
\Delta N_{i}=\left[\Delta v_{i}-\frac{V_{m}\left(F_{n, i}-F_{n, 0}\right)}{F_{n, i}}\right] K_{n} l
\end{array}\right\}
$$

\section{（3） ジョイントのせん断}

ジョイントのせん断変形とせん断応力の関係として, 図一6 (c) に示すモデルを利用する.モデルの構成関係 は図中の I Vの範囲でそれぞれ定義されるが，せん断 剛性率を $K_{s}$, 最大せん断応力を $\tau_{p}$, 残留応力を $\tau_{r}$ と すると，修正荷重を求めるための式は以下のようにな る.

$$
\left.\begin{array}{l}
F_{s, i}=l K_{s} \Delta u_{i}+\left(F_{s, 0}\right)_{i} \\
\Delta S_{i}=\tau_{i} l-F_{s, i} \\
\left(F_{s, 0}\right)_{i+1}=\left(F_{s, 0}\right)_{i}+\Delta S_{i}
\end{array}\right\}
$$

一方, ジョイント内を流れる水の挙動についても多く の理論的・実験的研究が実施されており ${ }^{16)}$, 式 (11) の 開口幅 $b$ に関する項は流速に対し 3 乗になるという報 告17)もなされているが，本研究では式（10）をそのまま 使用する.

\section{5. 解 析 例}

上記に説明したカップリング問題の対象となる地盤工 学上の事例はきわめて多いが，ここでは非常に簡単な例 を 2 つ挙げる. 1 つは不連続面をもつ地盤における揚 水・注水問題で不連続面の材料非線形のみが繰り返し計 


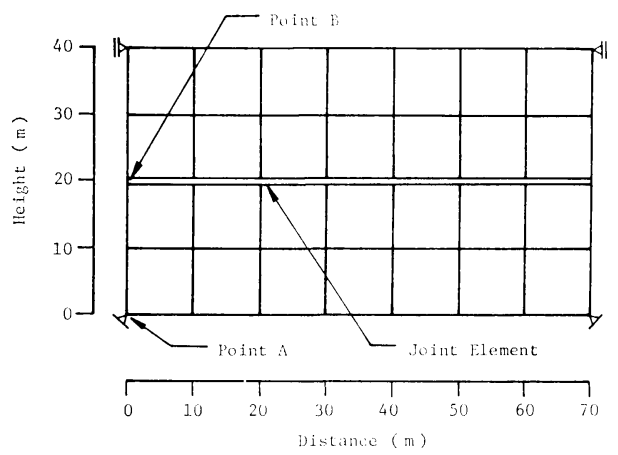

図一7揚水・注水問題解析モデル

算の対象となる．次に不連続面の近くにトンネルを掘削 したときの地盤の解析である.この場合, 浸出面がトン ネル空洞に出現するので繰り返し計算は複雑となる.こ れら 2 つの解析例を用いて, 本論文で示した基本式の適 用性について検討する.

\section{（1）揚水 ·注水問題}

解析に用いた地盤モデルでは，図一7に示すような水 平な不連続面が存在している.この地盤構成は比較的透 水性のよい泥岩からなる地盤を想定しており，各材料定 数は表一1に示した.ここでジョイント要素は不連続面 を表わすものであり，その内部は水のみが充満している 場合を考えている.

解析は, 揚水および注水を行ったときの地盤の挙動に 注目したものであり，比較のために不連続面を有しない 場合の解析も適宜行った. 解析は合計 5 つの場合を対象 にして㧍り，その内容を表-2 に示した. Case-1 から

\section{表一1 解析に用いた材料定数}

\begin{tabular}{|c|c|}
\hline Material Type & Material Properties \\
\hline Porous Media & $\begin{array}{l}\text { Young's Modulus } E=100000 \mathrm{tf} / \mathrm{m}^{2} \\
\text { Permeability } \quad k=1.0 \times 10^{-7} \mathrm{~m} / \mathrm{sec} \\
\text { Initial Void Ratio } e_{0}=0.5 \\
\text { Poisson's Ratio } \nu=0.33 \\
\text { Unit Weight } \quad r=1.6 \mathrm{tf} / \mathrm{m}^{3}\end{array}$ \\
\hline Joint & $\begin{array}{l}\text { Initial Normal Stiffness } \quad K_{n}=72000 \mathrm{tf} / \mathrm{m}^{3} \\
\text { Initial Tangential Stiffness } K_{s}=1000 \mathrm{tf} / \mathrm{m}^{3} \\
\text { Initial Permeability of Joint } \\
\qquad \begin{array}{l}k^{j}=5.787 \times 10^{-6} \mathrm{~m} / \mathrm{sec} \\
\text { Maximum Closure } \quad V_{m c}=0.05 \mathrm{~m} \\
\text { Initial Aperture } \quad V_{\text {int. }}=0.83 \times 10^{-3} \mathrm{~m}\end{array}\end{array}$ \\
\hline
\end{tabular}

表一2 解析モデルー筧表

\begin{tabular}{c|c|c|c}
\hline Case & Condition & $\begin{array}{c}\text { Existence } \\
\text { of Joint }\end{array}$ & $\begin{array}{c}\text { Given Pressure } \\
\text { Change at the } \\
\text { Well }\end{array}$ \\
\hline Case-1 & Withdrawal at A & Yes & $40 \rightarrow 0 \mathrm{tf} / \mathrm{m}^{2}$ \\
Case-2 & Withdrawal at A & No & $40 \rightarrow 0 \mathrm{tf} / \mathrm{m}^{2}$ \\
Case-3 & Withdrawal at B & Yes & $20 \rightarrow 0 \mathrm{tf} / \mathrm{m}^{2}$ \\
Case-4 & Withdrawal at B & No & $20 \rightarrow 0 \mathrm{tf} / \mathrm{m}^{2}$ \\
Case-5 & Injection at A & Yes & $40 \rightarrow 60 \mathrm{tf} / \mathrm{m}^{2}$ \\
\hline
\end{tabular}

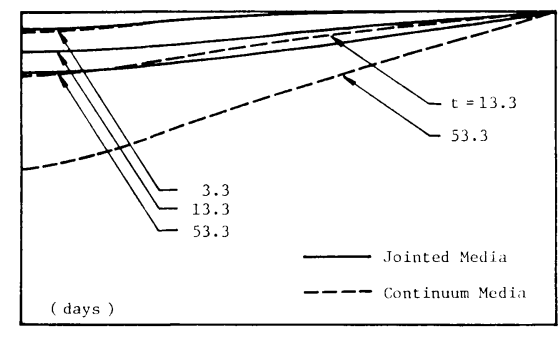

図一8 自由水面位置の経時変化（ポイント A揚水）

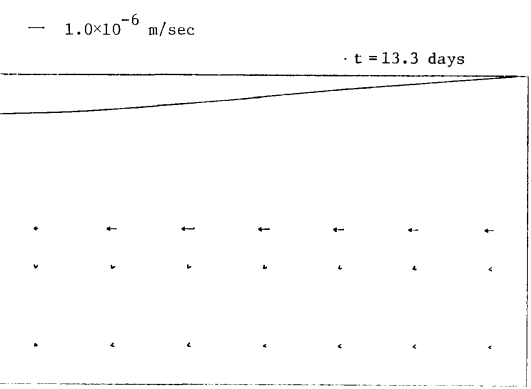

(a) Case 1

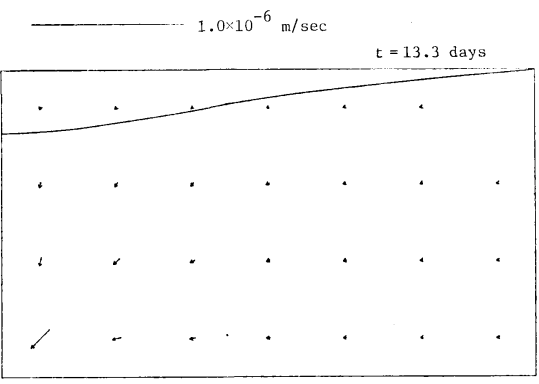

(b) Case 2

図一，流速分布

Case-4 の例は 図一7 の中の点 $\mathrm{A}$ または B の井戸にあた るところから揚水した場合である.外的条件としてその 井戸に与えた圧力変化も表一2 に表示されている. Case-5 は点 A での注入の例であり, 井戸の圧力を上昇 させている.

図一8 は Case-1 と Case-2 の自由水面の経時変化を 比較したものである. この図に示すように，初期の段 階では自由水面の低下にあまり差が生じていないのに対 し，時間が経過するにつれて，不連続面を有する場合の 方の低下が小さくなり大きな差が生じている.

次に，図一9 に流速分布を示す．ここで不連続面を有 する場合の流速を，不連続面を有しない場合の $1 / 10$ の スケールに掠いて示している. Duguid ら ${ }^{18)}$ の指摘にも あるように，不連続面を有する地盤においては，その体 積は地盤のごく一部でしかないのに対して，その流れは 大部分がこの不連続面によることが認められている.こ の土中水の流れが不連続面により強く支配される傾向 
が, 図一9において示されている.この場合，不連続面 内の流速は, 他の多孔質体の部分に比較して1オーダー から 2 オーダー高くなっている. 不連続面を有しない場 合には，この流れの向きは全体に揚水点の方向を示して いるが，不連続面を有する場合には，不連続面内の流れ が卓越することにより不連続面の上部で水平流れが支配 的なものとなっている. そしてまた，不連続部での流量 が大きくなるため, 全体的にみた場合, 不連続面のない ときと比べて不連続面に直交する方向への水の流れが妨 げられたのと同じ形となり，結果的に不連続部で水が貯 留されるといら効果から自由水面の低下が小さなものに なると考えられる.

次に, 図-10 に Case-1 と Case-2 の主応力図を示 した. この場合, 自由水面の低下の範囲の違いにより変 形量自体が Case-2 の方が大きくなるので, Case-2 の 主応力が全体的に Case-1 に比較して大きくなってい る. また, Case-1 ではジョイントの上面での水平変位

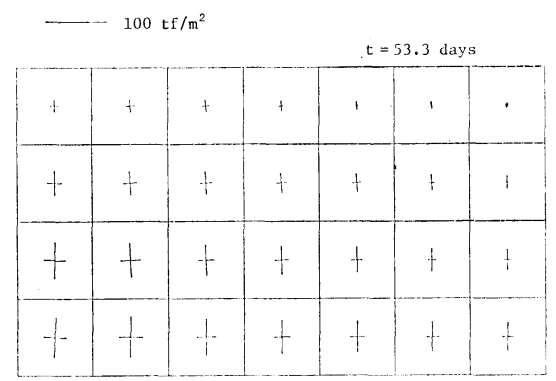

(a) Case 1

\begin{tabular}{|c|c|c|c|c|c|c|}
\hline \multicolumn{1}{c|}{$100 \mathrm{tf} / \mathrm{m}^{2}$} \\
\hline$t$ & + & $t$ & $t$ & $t$ & $\cdot$ & $\cdot$ \\
\hline$t$ & $t$ & + & $t$ & $t$ & $t$ & 1 \\
\hline$t$ & $t$ & $t$ & $t$ & $t$ & $t$ & $t$ \\
\hline$t$ & $t$ & $t$ & $t$ & $t$ & $t$ & $t$ \\
\hline
\end{tabular}

(b) Case 2

図一10 主応力分布

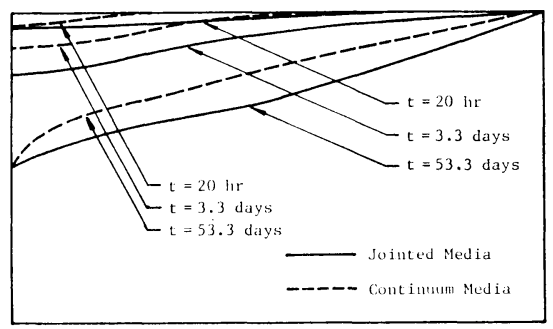

図一11 自由水面位置の線時変化（ポイントB揚水）
がせん断抵抗性により妨げられるために，不連続面上部 での主応力軸の回転が小さくなっている.

以上は，不連続面に直交する方向への流れについて注 目したものであるが，図一11 に不連続面の方向へ揚水 する場合（Case-3, Case-4) の自由水面の経時変化を示 す. 図一8 に示した傾向とは逆に, Case-3 の不連続面 を有する場合の方が自由水面の低下は大きくなる傾向を 示している. この場合の流速分布を 図一12 に示すが, 不連続面を有する場合の方が, 広い範囲にわたって水の 流れが生じているのに対して，不連続面を有しない場合 には，水の流れは揚水点の近傍だけとなる傾向が認めら れる.したがって不連続面の方向へ揚水した場合には, その流れの卓越する方向性を利用することになり，土中 水の運動は促進されることになるものと思われる.

図一13に Case-5 の注水の場合の 間隚水圧分布を示 した.この図に示すように, 注水圧の影響は注水点の付

$$
-1.0 \times 10^{-6} \mathrm{~m} / \mathrm{sec}
$$

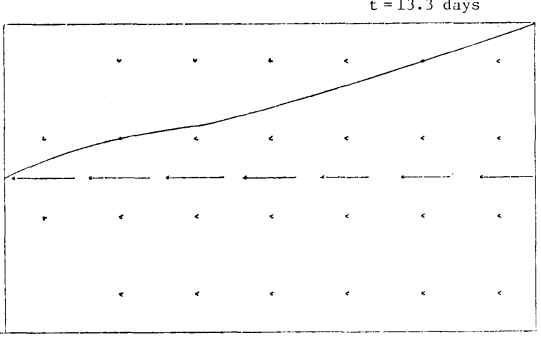

(a) Case 3

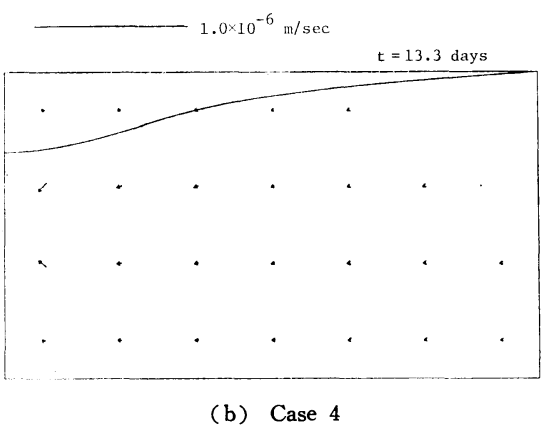

図一12 流速分布

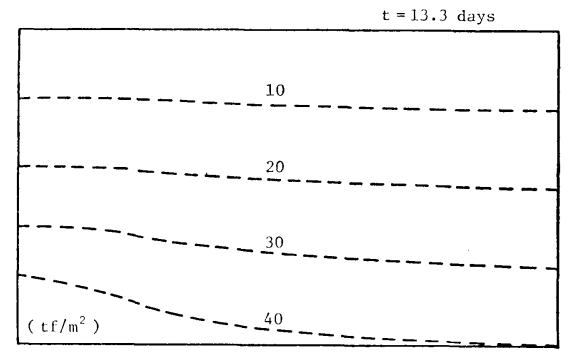

図一13 間隙水圧分布（Case 5) 

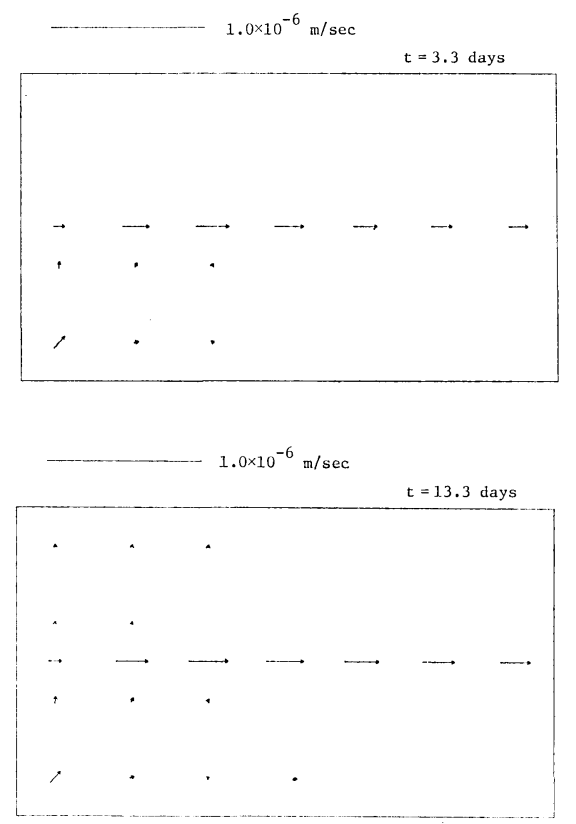

図-14 流速分布（Case 5)

近のみに現われ，また不連続面の影響により，この不連 続面より上部への間隚水圧の伝播は妨げられるような傾 向が現われている. この傾向は, 図一14の流速分布に も現われ，不連続面内の水の流れが支配的になり，これ より上部での土中水の流れは小さなものとなっている. このような傾向もまた, 前述の不連続面の影響によるも のと考えられる.

\section{（2）トンネル掘削問題}

軸対称場においては土中水の影響半径を推定する手法 が検討されている.ここでは, 平面ひずみ場の解析では あるが，図一15に示すモデル地盤の影響半径は $1000 \mathrm{~m}$ と仮定した. なお，解析結果に対してトンネル断面から $200 \mathrm{~m}$ 以上離れた領域への影響は小さいものと仮定し て, 以下の解析結果の図はすべて $200 \mathrm{~m}$ 以下の部分の みを示した. 計算に用いた定数は表一1に示したものと 同じである.

図一16 にトンネル 掘削に伴ら自由水面の経時変化を 示した. 自由水面の低下形状は, 不連続面をはさんで折 れ曲がる傾向を示す. 不連続面の左右の領域での自由水 面の形状を比較すると, 明らかに不連続面以遠での自由 水面の低下は緩やかであり, 不連続面とトンネル断面と の間で自由水面の低下は急激である.このような傾向 は，図一17に示す閒隚水圧分布においてより顕著に現 われている.この間隚水圧分布図において, 初期の段階 で間隚水圧の低下寸る領域は, トンネル断面と不連続面 との間の部分のみに限定されている. 時間の経過に伴

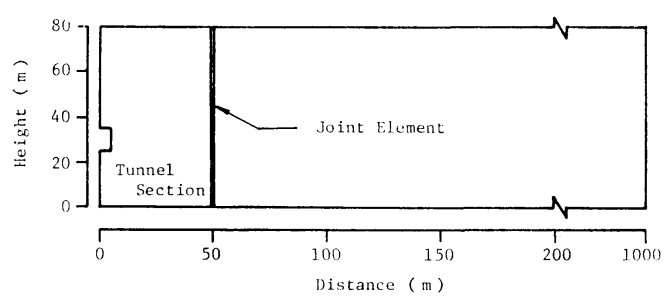

図一15 トンネル掘削問題解析モデル

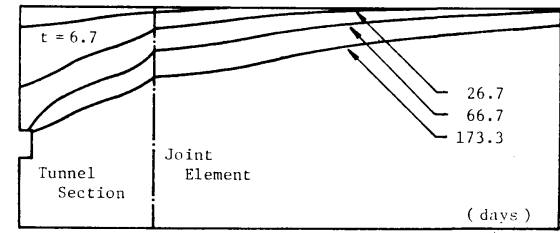

図-16 自由水面位置の経時変化
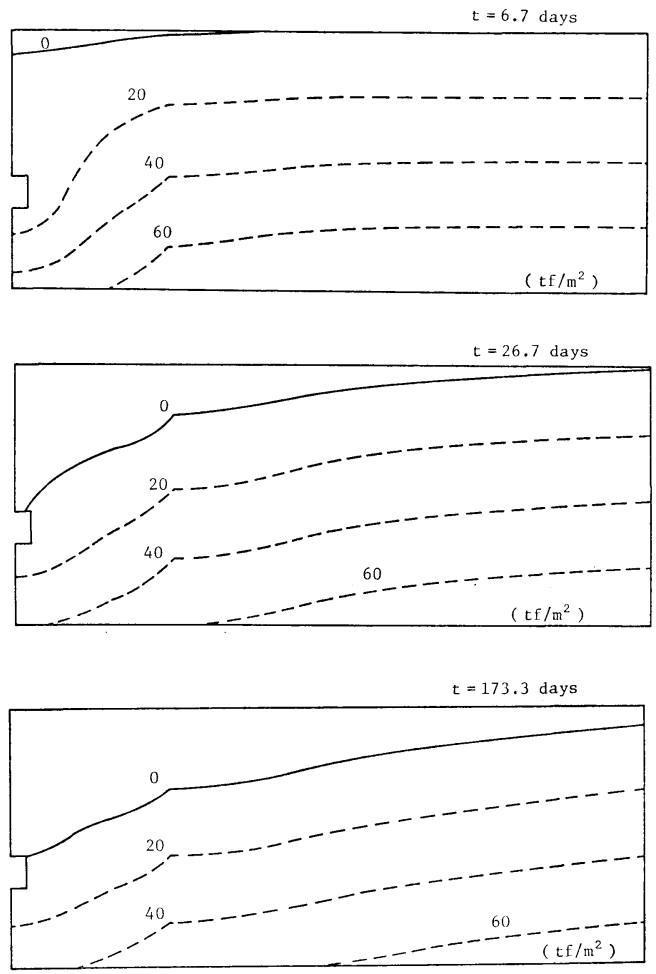

図一17間隙水圧分布の時間的変化

い，間隚水圧の低下の範囲はしだいに広がっていくが， 間隚水圧の分布は明らかに不連続面において折れ曲がる 傾向が認められる.

図一18 に示す流速分布図においても，土中水の流れ は不連続面内の流れが支配的である. また, その流速は 連続体部分と比べ, 1 オーダーから 2 オーダー大きくな っている. 不連続面以遠では, ほとんど轻平に近い流れ となり，不連続面では，その影響により鉛值な流れが生 


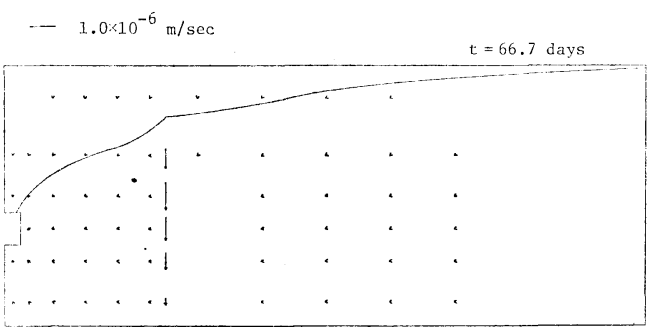

図一18流速分布
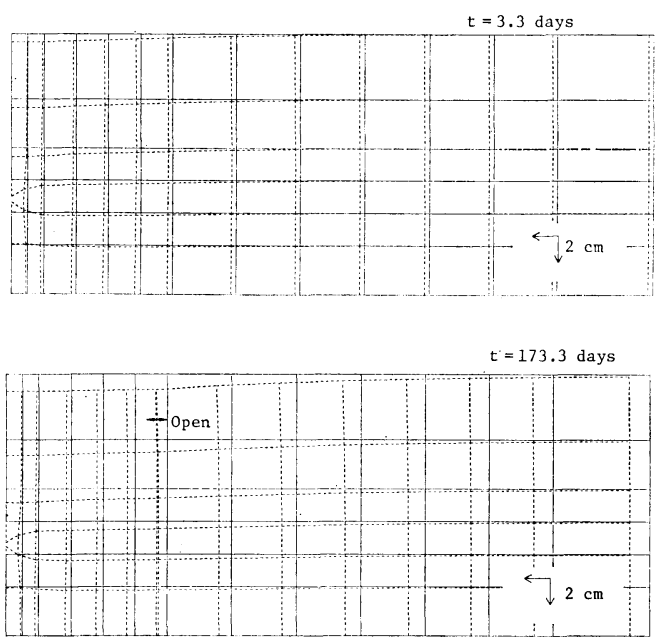

図一19 トンネル掘削と地下水流出による変形

じている. つまり不連続面の透水性がその不連続面の方 向に卓越することにより, 不連続面以遠から内側への土 中水の供給が妨げられることが予想される. したがっ て, 図一16の自由水面および 図一17 の間隙水圧分布に 示すように, 不連続面とトンネル断面の間の領域での圧 力の低下傾向は促進され, 一方不連続面以遠の領域では 逆にこの低下傾向は緩やかなものになると考えられる.

図一19 はこのときの変形図である. 鉛直変位に関し ては，全体的に沈下する傾向にあるが，この沈下の形状 は図一16 に示す自由水面の低下の形状と類似している. つまり, 自由水面の低下と同様に不連続面より内側ほど 大きな鉛直沈下量を示している.これは，不飽和領域の 発生による浮力の消散に伴う荷重条件の変化の影響によ るものと思われる. 水平変位に関しては, 土中水の運動 の方向性により, 全体的に深さ方向に対して多少ではあ るが上ほど大きくなる傾向を示す. なお，この図に示し ていないトンネル断面より $200 \mathrm{~m}$ 以上離れた領域では, 鉛直変位と水平変位はそれぞれ横方向および縦方向に一 様な変形になっている. 不連続面自体の変形状態に注目 して, ジョイント要素の変形形態を 図-20 に示した. 初期の段階では左右の両面は, 微小でかつほとんど同じ ような変形をするので, 明確な差は生じていない。しか
し，時間の経過ととも にしだいに開いていく 傾向にあるが，これは 以下のような理由によ るものと考えられる. 前述のよらに, 不連続 面においては土中水の 流れが阻止され，下方 に流れることにより間 隙水圧の不連続性が生 じる.このために，不 連続面より内側の領域 で間隚水圧の低下が急 激になることが恝めら れる.つまり，一度貯 留された土中水がトン ネル方向へ移動しよら とする力が, 不連続面

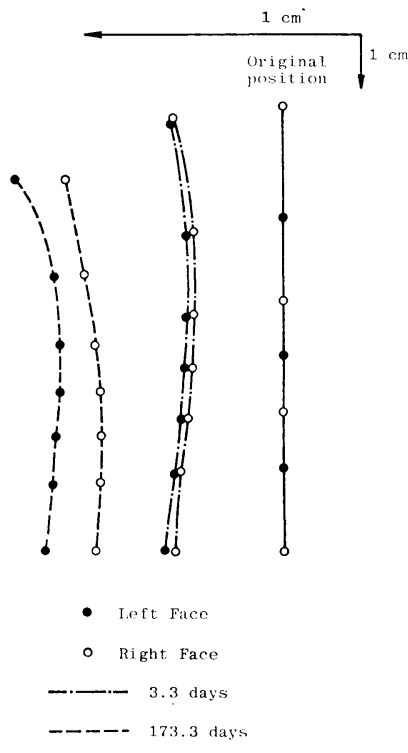

図一20 ジョイント要素の変位

へ流入しようとする力より大きくなり，全体的に領域が トンネル方向に変形するとともにトンネル断面に近い方 の面が比較的大きく水平に変位しようとすることにな る.

次に, 図一21 に主応力分布図を示した。この図にお いて, 初期の段階では, 応力の変動は変形と同様にトン ネル断面の周辺でのみ生じている．また，トンネル断面 から離れた部分では, 一様な変形をするために主応力軸 の回転があまりみられず，鉛直有効応力および水平有効 応力がそれぞれ主応力となり, 一様に応力が増加してい る傾向がみられる.この図において注目されることは， 自由水面の低下に伴い不飽和領域になる部分での主応力

\begin{tabular}{|c|c|c|c|c|c|c|c|c|c|c|c|}
\hline & & 10 & $t f$ & $/ m^{2}$ & & & & \multicolumn{4}{|c|}{$\mathrm{t}=2.0 \mathrm{hr}$} \\
\hline$* *$ & * & + & + & + & 4 & $t$ & + & t & t & + & + \\
\hline$+x$ & $t$ & t & $t$ & t & t & t & t & t & t & t & t \\
\hline$x A$ & $F$ & t & t & t & $t$ & t & + & - & t & $!$ & + \\
\hline$H$ & 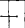 & - & $t$ & 7 & $T$ & $t$ & + & + & + & 4 & + \\
\hline$x+1$ & $f$ & - & t & - & + & + & + & - & + & 7 & 4 \\
\hline 11 & 1 & 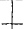 & . & 1 & 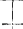 & $\perp$ & 1 & -1 & $\ldots$ & $\ldots$ & 1 \\
\hline inI & 1 & 1 & I & 1 & 1 & & & & & & \\
\hline
\end{tabular}

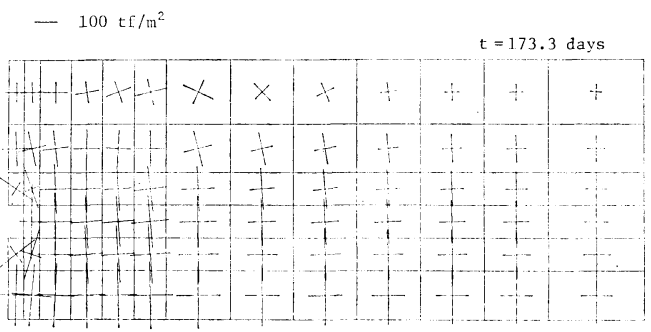

図-21 主応力分布 
の変化状況である.この領域では, 徐々に水平方向の変 形が増加することにより, 水平有効応力が増加し, 部分 的には鉛直有効応力ょりも大きくなる.このために，主 応力軸の回転が生じる．また，不連続面が不飽和領域に なる場合, これに隣接する部分において，この傾向が特 に顕著になっていると思われる.

\section{6. 結 論}

本論文では，現実の地質条件その他により問題となる 不連続面を有する地盤ならびに岩盤の一般的な挙動を解 析する一つの手法を提示した. その特徴は応力・変形解 析と浸透流解析を同時にカップリング問題として取り扱 らことであり, その骨子は有限要素法による数值解析で ある. 不連続面を表現するものとしてジョイント要素を 採用し, ジョイント内の水の流れは, 平行板モデルを想 定し, 非圧縮性流体の理論から導いた式を 1 次元アイソ パラメトリック要素を用いて定式化した。また，連続な 多孔質部分と不連続面の間の内部境界での流出および流 入を 2 つのメディアでの相互作用としてとらえ，これを 考慮した.

モデル地盤の解析結果によると, 土中水の運動は不連 続面の存在に強く影響され，不連続面に沿ら方向への流 れは促進されるが，それと直交する流れは妨げられると いら傾向が認められている. 応力・変形特性も不連続面 の存在により, 連続性解析と大きく異なった結果が得ら れる.

本論文においては，不連続面の透水性が他の部分より かなりよい例を解析した。しかし，不連続面内に風化し て粘土化した土が詰まっていて逆に透水性が悪化してい るような場合も考えられるが，計算手法上は定数の変更 だけで対応できる.ここに示した手法は，不連続性岩盤 の応力・変形・浸透流解析に限らず, 岩盤へのグラウト 解析, 構造物と地盤あるいは異種材料間の接触や剝離の 解析など非常に広い応用範囲があるものと思われる．有 限要素法を用いた本解析手法の今後の課題はジョイント の力学的・水理学的材料定数の室内ならびに原位置での 正確な決定 ${ }^{19)}$, 解析対象, 特にジョイントネットワーク のモデル化, 不飽和領域の定義, 非線形解析の効率向上 による計算時間の短縮などであると考えられるため, こ れからの関連分野での研究・開発の進歩, 計測手法の進 展, 計測データの蓄積が期待される.

最後に，本研究を遂行するにあたり終始適切な助言を いただいた京都大学 赤井浩一教授に深く感謝いたしま す.

\section{参 考 文 献}

1) Goodman, R.E. and C. St. John : Finite Element Analysis for Discontinuous Rocks, Chapter 4, Numer- ical Methods in Geotechnical Engineering, Ed. by Desai and Christian, McGraw-Hill, 1977.

2) Goodman, R.E., R.L. Tayler and T.L. Brekke : A Model for the Mechanics of Jointed Rock, J. of GT Div., ASCE, Vol. 94, 1968.

3) Serafin, J.L. : Influence of Interstitial Water on Behavion of Rock Masses, Chapter 8, Rock Mechanics in Engineering Practice, Ed. by Stagg and Zienkiewicz, Wiley, 1968.

4) Wilson, C. and P.A. Witherspoon : An Investigation of Laminar Flow in Fractured Porous Rocks, Geotech. Eng. Report, No. 70-6, Univ. of Calif., Berkeley, Calif., 1970.

5) Wilson, C. and P.A. Witherspoon : Steady State Flow in Rigid Networks of Fractures, Water Resource Res., Vol. 10, No. 2, 1974.

6) Wittke, W., P. Rissler and S. Semprich : Three Dimensional Laminar and Turbulent Flow through Fissured Rock according to Discontinuous and Continuous Models, Proc. Symp. on Percolation through Fissured Rock, Stuttgart, 1972.

7) Maini, Y.N.T. :In Situ Hydraulic Parameters in Jointed Rock-Their Measurement and Interpretation, $\mathrm{Ph} . \mathrm{D}$. Dissertation, Imperial College, London, 1971.

8) Warren, J.E. and P.J. Root: The Behavior of Naturally Fractured Reservoirs, J. Soc. of Petroleum Engineers, Sept., 1963.

9) Gringartain, A.C. and P.A. Witherspoon : A Method of Analysing Pump Test Data from Fractured Aquifers, Proc. Symp. on Percolation Through Fissured Rock, Stuttgart, 1972.

10) Snow, D.T. : Fracture Deformation and Changes of Permeability and Storage upon Changes of Fluid Pressure, Quarterly, Colorado School of Mines, Vol. 63, No. 1, 1968.

11) Bernaix, J. : New Laboratory Methods of Studying the Mechanical Properties of Rocks, Int'l J. of Rock Mech. and Mining Sci., Vol. 6, No. 1, 1969.

12) Noorishad, J., P.A. Witherspoon and T.L. Brekke : A Method of Coupled Stress and Flow Analysis of Fractured Rock, TE-71-6, Univ. of Calif., Berkeley, Calif., 1971.

13）山上拓男：変形し得る多孔体中の流れの支配式に関する 考察, 土木学会論文報告集, No. 304, 1980.

14）大西有三・村上 毅：有限要素法による地盤の応力・変 形を考慮した浸透流解析, 土木学会論文報告集, No. 298 , 1980.

15) Goodman, R.E. : Methods of Geological Engineering, West Pub. Co. (日本語訳, 赤井ほか：不連続性岩盤の 地質工学, 森北出版), 1976.

16) Gale, J.E. : A Numerical, Field and Laboratory Study of Flow in Rocks with Deformable Fractures, Ph.D. Thesis, Univ. of Calif., Berkeley, Calif., 1975.

17) Iwai, K. : Fundamental Studies of Fluid Flow Through a Single Fracture, Ph.D. Thesis, Univ. of Calif., Berkeley, Calif., 1976.

18) Duguid, J.O. and P.C.Y. Lee : Flow in Fractured Porous Media, Water Resource Res., Vol. 13, No. 3, 1977.

19）赤井浩一・大西有三：岩盤および構造物基礎の浸透流に 関する調查と設計手法の研究一岩盤の透水性を決定する 手法についての検討, 防災研究協会, 1980 .

(1981.5.18 - 受付) 